\title{
THE EFFECT OF WORKING CAPITAL TURNOVER ON PROFITABILITY (EMPIRICAL STUDY OF TEXTILE AND GARMENT COMPANIES LISTED ON THE INDONESIA STOCK EXCHANGE FOR THE 2014-2018 PERIOD)
}

\author{
Devita Sari ${ }^{1}$, Ignatius Oki Dewa Brata ${ }^{2}$ \\ Universitas Widyatama, Bandung,2 \\ Email: devita.sari@widyatama.ac.id ${ }^{1}$, ignatius.oki@widyatama.ac.id ${ }^{2}$
}

\begin{abstract}
Cash flow from operating activities is the amount of cash flow originating from working capital is the right or part owned by the owner of the company indicated in the postal capital (share capital), surplus and retained earnings (S. Munawir, 2010: 19). Profitability is a ratio to assess a company's ability to find profits or profits in a certain period. This ratio can also provide a measure of the level of effectiveness of company management which can be shown from the profits obtained from sales or from investment income (Kasmir, 2015: 22). In this study the authors use quantitative methods, with descriptive research approaches and verification analysis. by using the research method will be known a significant effect between the variables studied so that conclusions that will clarify the picture of the object under study, the sample in this study were 14 companies The analytical tool used in this study uses simple linear regression. Based on the research results, the profitability represented by ROA is influenced by the working capital turnover. Working Capital Turnover does not have a significant effect on Return of Assets.
\end{abstract}

Keywords: working rounds of working and return of asset.

\section{INTRODUCTION}

Instability of Macroeconomic beginning with the rising world oil and interest rates of international that affect to the inflation. The uncertainty of the policy in question, in terms of tax rules, licensing and implementing of imports which are important factors for competitiveness of a unit of business, the decline of imports of capital goods to total import and rising role of imports of consumer goods describes manufacturing industry in 2018 weakening. The data of the Indonesian fiberment and fiberment association also explained that the performance of TPT 
trade in 2018 became the worst throughout history because the exports only grew $0.9 \%$, while imports grew up to $13.9 \%$ so that the trade balance of TPT deficit 25.6\%. The condition is created due to the Permendag number of 64 years 2017 on the provision of Import Textiles and Textile Products. In this policy, the government gives the green light to the merchant (API-U) to import textile raw materials through the Bonded Logistics Center (PLB).

This condition causes products from the upstream industry, especially in the fabric manufacturing sector to compete with imported fabrics and are less absorbed by the downstream garment industry. Redma said that currently production utilization in the weaving, knitting and fabric dyeing sectors is only in the range of $40 \%$. The financial performance used in this study by looking at Return On Assets (ROA) in the textile and garment industry which was listed on the Indonesia Stock Exchange for the period 2014-2018, as follows:

Tabel 1. Return On Assets Texture and Garment Industry listed on the Indonesia Stock Exchange in the December 2014-2018 period

\begin{tabular}{|c|l|r|r|r|r|r|}
\hline \multirow{2}{*}{ No } & & \multicolumn{5}{|c|}{ ROA (\%) } \\
\cline { 3 - 7 } & & \multicolumn{1}{|c|}{2014} & \multicolumn{1}{c|}{2015} & \multicolumn{1}{c|}{2016} & \multicolumn{1}{c|}{2017} & \multicolumn{1}{c|}{2018} \\
\hline 1 & PT. Roda Vivatek Tbk & 14.15 & 13.92 & 12.32 & 10.83 & 11.73 \\
\hline 2 & PT. Apac Citra Centretex Tbk & -7.75 & -13.57 & -22.01 & -17.1 & -15.54 \\
\hline 3 & PT. Argo Pantes Tbk & -20.80 & -8.38 & -22.14 & -0.15 & -0.09 \\
\hline 4 & PT. Asia Pacific Fibers Tbk & -29.07 & -7.65 & -5.13 & -1.85 & 5.39 \\
\hline 5 & PT. Centex & 0.01 & 0.04 & 0.04 & -0.04 & -0.03 \\
\hline 6 & PT. Eratex Djaja Tbk & 4.86 & 9.94 & 2.96 & -3.0 & 1.7 \\
\hline 7 & PT.Ever Shine Textile Industry Tbk & -9.17 & -18.17 & 6.33 & -2.8 & 2.3 \\
\hline 8 & PT. Indorama Synthetic Tbk & 0.54 & 1.26 & 0.17 & 0.2 & 7.7 \\
\hline 9 & PT. Star Petrochem Tbk & 0.04 & 0.04 & 0.07 & -21 & -5 \\
\hline 10 & PT. Tifico Fiber Indonesia Tbk & -1.36 & -0.52 & 1.93 & 1 & -1 \\
\hline 11 & PT. Nusantara Inti Corpora Tbk & 0.06 & 0.08 & 0.20 & 0.25 & 0.12 \\
\hline 12 & PT. Pan Brothers Tbk & 2.76 & 1.95 & 2.56 & 1.50 & 2.89 \\
\hline 13 & PT. Trisula International Tbk & 6.86 & 6.52 & 3.94 & 3.63 & 3.13 \\
\hline 14 & PT. Panasia Indosyntec Tbk & -2.50 & -7.29 & -8.30 & -0.2 & -0.4 \\
\hline 15 & PT. Sunson Textile Manufacture & -1.66 & -1.45 & -2.17 & -4.21 & 0.50 \\
\hline 16 & PT. Polychem Indonesia Tbk & -5.30 & -5.75 & -5.40 & -1.6 & 1.3 \\
\hline 17 & PT. Unitex Tbk & 4.00 & 6.30 & 9.50 & 0.90 & 6.90 \\
\hline 18 & PT. Ricky Putra Globalindo Tbk & 1.00 & 1.10 & 1.00 & 1 & 1 \\
\hline 19 & PT. Sri Rejeki Isman Tbk & 7.22 & 7.11 & 6.27 & 5.70 & 6.20 \\
\hline
\end{tabular}

Source: Indonesia Stock Exchange (IDX) 
Based on the data above it can be seen that the level of profitability in textile and garment companies listed on the Indonesia Stock Exchange in 2014-2018 has fluctuated. This can be seen from the average level of profitability in 2014 to 2015 which has increased but in 2016 it has again declined. Even in 2011-2017 the level of profitability was negative. Brigham and Houston, (2006: 115) suggested that "The average value of ROA for the industry is $9 \%$. In the table above, it appears that all companies have below average profitability values. This is a problem and must be addressed immediately. A company if it has a low level of profitability even tends to negatively show the prospects of a company that is not good in the future, because the higher the level of profitability of a company shows the survival of the company is guaranteed. Negative profitability indicates that the company suffered losses from the use of its activities. That is, the total active of the company cannot provide profits or profits for the company. This will have several impacts, one of which is the loss of trust from outside parties, especially creditors or investors.

Return On Assets (ROA) is a ratio used to measure the ability of company management to obtain overall profits (Dendawijaya, 2009). Return On Assets (ROA) can show how the company's performance can be seen from the overall use of assets owned by the company in generating profits (A.A.Wela, 2015: 2). ROA ratio is often used by management to measure the company's financial performance and assess operational performance in utilizing the company's resources, besides the need to consider financing problems for these assets, the value of ROA is getting closer to one, which means the better profitability of the company because every existing asset can produce profit, in other words the higher the value of ROA, the better the company's financial performance. Kasmir(2013: 250), states working capital is capital that is used to carry out company operations, working capital is defined as investments that are invested in current assets or short-term assets. Furthermore according to Kasmir (2011: 182) working capital turnover is one of the ratios to measure or assess the effectiveness of company working capital during a certain period means how much working capital revolves during one period or in one period, the higher the working capital turnover, the better the company's performance in generating profits for a certain period.

Furthermore Radhi Abdul Halim's research from Lecturer of Widyatama University Year (2015) with the title Effect of Effectiveness of Working Capital Management and Fixed Assets on Net Profit Margin concluded that the effectiveness of working capital and fixed assets affected Profitability (profit margin) with a magnitude of influence of $4.6 \%$ then Radhi's (2015) lecturer at Widyatama University titled the effect of Leverage on Profitability with the 
April, 2020

results of Leverage significantly positive effect on The Reason Of Profitability is leverage is one of the tools used by companies to increase their capital in order to increase profits.

\section{FRAMEWORK}

According to Mamduh M. Hanafi (2012: 81) definition of profitability is a ratio to measure a company's ability to generate profits at a certain level of sales, assets and share capital. There are 3 (three) most commonly used ratios namely Profit Margin, Return on Assets (ROA) and Return on Equity (ROE). According to Sudana (2012: 22) definition of profitability is a ratio to measure the ability of a company to get profits by utilizing the company's resources such as assets, capital or company sales. According to Kasmir (2015: 22) definition of profitability is a ratio to assess a company's ability to look for profits or profits in a certain period. This ratio can also provide a measure of the effectiveness of the company's management which can be shown from the profits derived from sales or from investment income. According to Sartono (2012: 122) definition of profitability is a ratio to measure the ability for companies to generate profits in terms of sales, assets or profits. For long-term investors, they have an interest in this profitability analysis, for example shareholders see the potential profit that can be received in the form of dividends.

Regarding the definition of working capital, put forward by several experts including (Brigham, Eugene and Joel F. Houston, 2013) working capital, or sometimes also called gross capital, is actually a smooth asset used in operations. Working capital is a very important factor in a company besides fixed assets. Availability of capital that can immediately be used in operations depends on the type of current assets owned companies such as cash, receivables and securities.

Working capital is the right or part owned by the owner of the company indicated in the capital account (share capital), surplus and retained earnings (Munawir, 2014: 19).

Definition of working capital according (Jumingan, 2006: 66) there are two, namely as follows:

1. Working capital is an excess of current assets against short-term debt. This excess is called net working capital.

2. Working capital is the sum of current assets. This amount is gross working capital.

From the above definition, it can be concluded that there is a difference regarding working capital, which is the overall amount of current assets in the company. And working capital as an excess of current assets is called net capital working and which is overall current assets called gross working capital. Auditing is a science that is used to conduct an assessment of internal control aimed at 
April, 2020

providing security and protection in order to detect the occurrence of fraud and irregularities committed in the company. there are several definitions of auditing in the opinion of experts: Mulyadi (2013: 9) Definition of auditing is In general auditing is a systematic process for obtaining and evaluating evidence objectively about statements about economic activity and occurrence, with the aim of determining the level of concordance between the statements with the established criteria, and the delivery of results to interested users. According to Arens, et al (2014: 02) Auditing is the collection and evaluation of evidence about information to determine and report the degree of conformity between information and criteria that have been set. Auditing must be carried out by a competent and independent person.

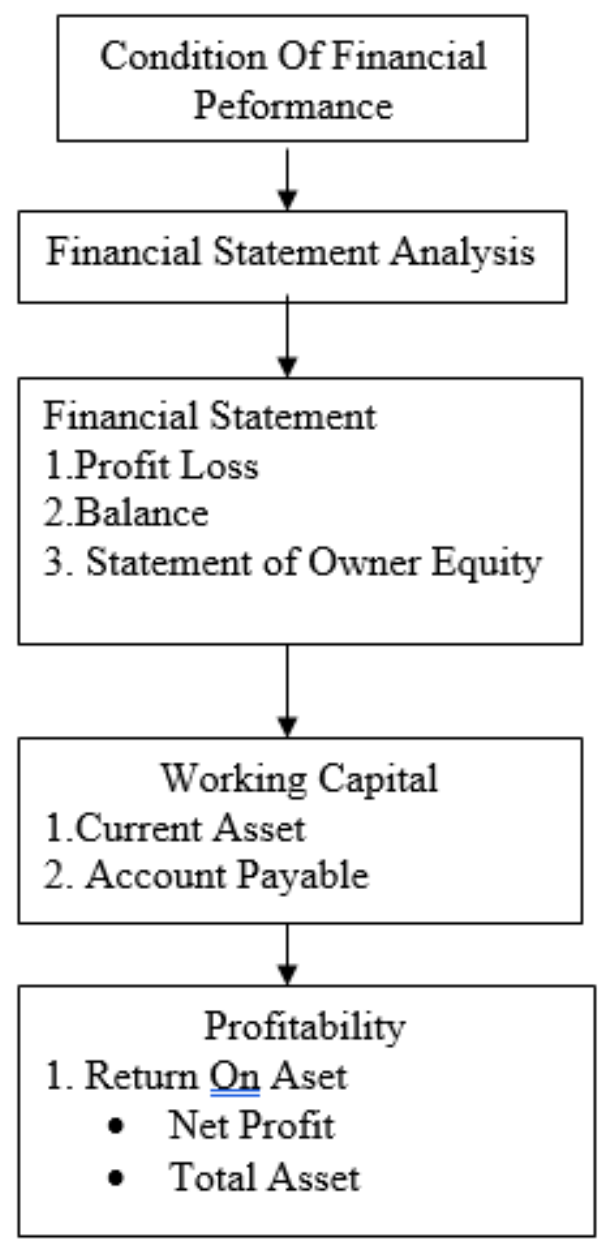

Figur 1. Research Framework

According to Sugiyono (2011: 64) explains the hypothesis as follows:

"Hypothesis is a temporary answer to the formulation of a research problem, where the research formulation has been stated in the form of a sentence statement. It is said temporarily, because the answers given are only based on 
relevant theories, not yet based on empirical facts obtained through data collection. So the hypothesis is also stated as a theoretical answer to the formulation of the research problem, not yet an empirical answer". Hypothesis based on the conceptual framework and theoretical description above, the researcher proposes the following hypothesis:

HA: Changes in Profitability are influenced by Working Capital

HO: Changes in Profitability are not influenced by Working Capital

\section{METHOD}

The method used is explanatory research. which is a method that aims to increase understanding of a phenomenon that has known what, who and how. A phenomenon that has been known to occur and has a detailed description can be further investigated to get an explanation, about the reasons why it happened (focus on answering why). Therefore this research looks for the causes and reasons behind a phenomenon.

As a further elaboration of the operationalization of variables, in the table presented measurements of the observed variables consisting of elements of variables, indicators and measurement scale. All indicators are measured on an ordinal scale level.

Table 2. Variable Operational Table

\begin{tabular}{|c|c|c|c|c|}
\hline Variable & Variable Concept & Indicato & & Scale \\
\hline \multirow{2}{*}{$\begin{array}{c}\text { Capital } \\
\text { Working } \\
\text { Turnover } \\
\text { (X) }\end{array}$} & \multirow{2}{*}{$\begin{array}{l}\text { Working capital is the right } \\
\text { of part owned by the owner } \\
\text { of the company indicated in } \\
\text { the capital account(share } \\
\text { capital), surplus and } \\
\text { retained earning } \\
\text { (S.Munawir, 2010:19). }\end{array}$} & \multirow{2}{*}{$\mathrm{WCT}=$} & Net Sales & \multirow[t]{2}{*}{ Ratio } \\
\hline & & & Capital Asset & \\
\hline \multirow[b]{2}{*}{$\begin{array}{l}\text { Profitability } \\
\text { (Y) }\end{array}$} & \multirow{2}{*}{$\begin{array}{l}\text { Profitability is a ratio to } \\
\text { assess a company's ability } \\
\text { to find profits or profits in } \\
\text { certain period. This ratio } \\
\text { can also provide a measure } \\
\text { of the effectiveness of } \\
\text { company's management } \\
\text { which can be shown from } \\
\text { the profits derived frome } \\
\text { sales or from investment } \\
\text { income (Kasmir,2015: 22) }\end{array}$} & \multirow{2}{*}{$\mathrm{ROA}=$} & Net Profit & \\
\hline & & & Total Asset & Ratio \\
\hline
\end{tabular}

The independent variable in this study is the working capital turnover that was given a notation (X) according to Kasmir in Caesarani (2014) working capital turnover is one of the ratios to measure or assess the effectiveness of the company's working capital during a certain period. Meanwhile according to Munawir (2010: 80) "This ratio shows the number of working capital sales that 
might be caused by the low availability, accounts receivable or the existence of a cash balance that is too large". The dependent variable in this study is profitability using ROA which is given a notation (Y) according to this ratio shows how much net income the company gets when measured from the value of its assets. According to Harahap (2009: 305), the greater the ratio the better because the company is considered capable of using its assets effectively to generate profits.

Regression analysis is an analysis used to predict the extent of changes in the dependent value, if the value of the independent variable is changed or increased. In this study, regression analysis is used to determine whether there is an influence between motivation on job satisfaction. In the regression equation used is a simple linear regression equation, because it is based on a functional or causal relationship of one independent with one dependent variable. So only see two variables, namely motivation as an independent variable and job satisfaction as the dependent variable. According to Sugiyono (2017: 188) the form of a simple linear regression equation uses the following formula:

Information:

$$
Y=a+b X
$$

$\mathrm{Y}=$ Subject of the dependent variable defined (Return of Asset)

$\mathrm{a}=$ Price of $\mathrm{Y}$ if $\mathrm{X}=0$ (constant price)

$\mathrm{b}=$ direction number or regression coefficient, which shows the cause of an increase or decrease in the dependent variable, based on changes in the independent variable. If $b(+)$ then there is an increase and if $b(-)$ then there is a decrease. $X=$ subject on the independent variable that has a certain value (working capital turnover)

\section{FINDINGS AND DISCUSSION}

Before analyzing statistical data, the author tries to explain the analysis relating to the data of each variable in this study, namely the Working Capital Turnover (X) variable, to Return of Assets (Y). Analysis of the data in this study using multiple linear regression analysis methods or techniques. Regression analysis is a statistical technique that is useful for examining and modeling relationships among variables. Where the application of regression is generally associated with the study of the dependence of a variable (dependent variable) on other variables (independent variables).

While multiple linear regression analysis is generally used to analyze the relationship between two or more independent variables. To determine the effect of Working Capital Turnover (X1) on Return of Assets (Y). With the help of SPSS 17.00 for Windows software, the results can be seen in the following table: 
April, 2020

Table 3. Coefficients of Regression Equations Table

\begin{tabular}{|c|c|c|c|c|c|c|}
\hline & \multirow[b]{2}{*}{ Model } & \multicolumn{2}{|c|}{ Unstandardized Coefficients } & $\begin{array}{l}\text { Standardized } \\
\text { Coefficients }\end{array}$ & \multirow[b]{2}{*}{$\mathrm{t}$} & \multirow[b]{2}{*}{ Sig. } \\
\hline & & B & Std. Error & Beta & & \\
\hline \multirow[t]{2}{*}{1} & (Constant) & -12.804 & 12.626 & & -1.014 & .340 \\
\hline & $\mathrm{X}$ & $-2.832 \mathrm{E}-11$ & .000 & -.164 & -.470 & .651 \\
\hline
\end{tabular}

a. Dependent Variable: $\mathrm{Y}$

From the table above the test shows the regression equation with the linear regression equation is multiple as follows:

$$
Y=\beta_{0}+\beta X
$$

Obtained are as follows:

$$
Y=-12804-2.832 E-11 X
$$

From the regression equation above it can be seen that the regression coefficient $\left(B_{\mathrm{i}}\right)$ for the variable Capital Working Turnover $(\mathrm{X})$ is negative means that the variable has a negative effect on Return of Assets (Y). Working Capital Turnover Variable $\left(\mathrm{X}_{1}\right)$, has a regression coefficient $\left(\beta_{\mathrm{i}}\right)$ of $-2,832 \mathrm{E}-11$. This shows that each increase in the Working Capital Turnover variable $(\mathrm{X})$, one unit of value will decrease the Return of Assets (Y) -2,832E-11 units of value, assuming the other variables are zero.

Table 4. Coefficients Of Determination

\begin{tabular}{l|c|c|c|c|}
\hline Model & $\mathrm{R}$ & R Square & $\begin{array}{c}\text { Adjusted R } \\
\text { Square }\end{array}$ & $\begin{array}{c}\text { Std. Error of the } \\
\text { Estimate }\end{array}$ \\
\hline 1 & $.164^{\mathrm{a}}$ & .027 & -.095 & 35.73070 \\
\hline
\end{tabular}
a. Predictors: (Constant), X
b. Dependent Variable: $\mathrm{Y}$

Based on the table above, the researchers found that the value of $\mathrm{R}$ square, which is considered to represent the coefficient of determination is amount 0.027 , which means $2.7 \%$ of the profitability represented by ROA is influenced by the rotation of working capital. While the remaining $97.3 \%$ there are outside influences that are not examined by researchers. To find out how much influence the Working Capital Turnover (X) variable on Return of Assets (Y). then the testing of the regression line will be done through the hypothesis.

Next will be tested the effect of each Working Capital Turnover (X) variable has a significant effect on Return of Assets (Y). The form of the hypothesis is as follows

HO : There is no influence of Working Capital Turnover (X) on Return of Assets (Y).

HI : There is a partial influence of Working Capital Turnover (X) on Return of Assets (Y). 
The test statistic used to test the above hypothesis is the t-test. To find out the direct effect individually, a t test must be done first. First the $t_{\text {count }}$ of each $X_{1}$ must be found, after that the $t_{\text {count }}$ is compared with the $t$-value in the table. If the value of $t_{\text {count }}$ is greater than the $t_{\text {table }}$ value, then the hypothesis is significant, meaning that the effect that occurs can be generalized to the entire population. Conversely, if the value of $t_{\text {count }}$ is smaller than the $t_{\text {table }}$ value, then the hypothesis is not significant, meaning that the effect that occurs cannot be generalized to the entire population. Based on the results of data processing as seen in the Coeffecients table, the value of $t_{\text {count }}$ is obtained.

Table 5. Coefficients ${ }^{\text {a }}$ Table

\begin{tabular}{|c|c|c|c|c|c|c|}
\hline & \multirow[b]{2}{*}{ Model } & \multicolumn{2}{|c|}{ Unstandardized Coefficients } & \multirow{2}{*}{\begin{tabular}{|l|}
$\begin{array}{c}\text { Standardized } \\
\text { Coefficients }\end{array}$ \\
Beta
\end{tabular}} & \multirow[b]{2}{*}{$\mathrm{t}$} & \multirow[b]{2}{*}{ Sig. } \\
\hline & & B & Std. Error & & & \\
\hline \multirow[t]{2}{*}{1} & (Constant) & -12.804 & 12.626 & & -1.014 & .340 \\
\hline & $X$ & $-2.832 \mathrm{E}-11$ & .000 & -.164 & -.470 & .651 \\
\hline
\end{tabular}

a. Dependent Variable: $\mathrm{Y}$

From the Coefficients table above, it can be concluded as stated in the thitung table of each independent variable as below. While the value of $t_{\text {table }}$ is the value of the distribution of $t$-student at the real level $(\alpha) 5$ Percentage with free degrees 23 . The conclusions that can be drawn are as follows:

Table 6. Conclusion Of Testing Individually Table

\begin{tabular}{|c|c|c|c|}
\hline Variable & Value tcount & Value t table & Conclusion \\
\hline $\mathrm{X}$ & -0.470 & 1.74 & Not Significant \\
\hline
\end{tabular}

\section{Source : calculation results}

From the table above it can be seen that all of them have insignificant influence. This means that if there is only a slight change in the Working Capital Turnover (X) variable, it will not immediately mean a significant change in the Return of Asset (Y) variable. In addition, the effect can be generalized to the entire population.

\section{CONCLUSION}

Based on the research that the author has done, the writer can draw the following conclusions: each increase in the Working Capital Turnover variable one unit of value will decrease the Return of Asset unit of value, assuming the other variables are zero. Based on the research results, the profitability represented by ROA is influenced by the working capital turnover. Working Capital Turnover does not have a significant effect on Return of Assets. 
April, 2020

\section{REFERENCES}

A.A Wela, Yulia Putra, Ida Bagus Badjra. 2015. Pengaruh Leverage, Pertumbuhan Penjualan dan Ukuran Perusahaan terhadap Profitabilitas pada Perusahaan Industri Makanan dan Minuman yang terdaftar di BEI. E-Jurnal Manajemen Unud, Vol.4 No.7, 2015: 2052-2067.

Brigham, Eugene dan Joel F. Houston.(2013). Dasar-dasar Manajemen Keuangan. Edisi Kesepuluh. Jakarta : Salemba Empat.

Dendawijaya, Lukman. (2009). ManajemenPerbankan. Jakarta: Ghalia Indonesia.

Jumingan, (2006). Analisis Laporan Keuangan, Cetakan Pertama. Jakarta: Bumi Aksara

Kasmir.(2012), Analisis Laporan Keuangan.Jakarta : PT. Raja Grafindo Persada.

Hanafi, Mahduh dan Abdul Halim, 2012, Analisis Laporan Keuangan. Yogyakarta: (UPP) STIM YKPN.

Munawir.(2014). Analisa Laporan Keuangan.Edisi keempat. Yogyakarta: Liberty.

Permendag Nomor 64 Tahun 2017 tentang Ketentuan Impor Tekstil dan Produk Tekstil

Radhi A.HR., (2015), Pengaruh Efektivitas Pengelolaan Modal Kerja dan Aktiva Tetap Terhadap Net Profit Margin, Vol 1 No 3 (2015): Jurnal Riset Bisnis \& Investasi, Politeknik Negri Bandung

Sartono, Agus. 2012. Manajemen Keuangan: Teori dan Aplikasi. Yogyakarta: BPFE.

Sudana, I Made. 2012. Manajemen Keuangan Perusahaan Teori dan Praktik.Jakarta: Erlangga.

Syakieb Arsalan (2016), Pengaruh Struktur Modal Dan Ukuran Perusahaan Terhadap Profitabilitas (Studi Pada Pabrik Tekstil Di Bandung 20052014),Jurnal Akuntansi Bisnis \& Ekonomi, Fakultas Ekonomi Universitas Widyatama Bandung

www.idx.com

Bisnis Dan Iptek | Sekolah Tinggi Ilmu Ekonomi Pasundan Bandung 